UDC: $330.101 ; 336.225 .61$

JEL Classification: $M 4$

doi: 10.31767/nasoa.4.2018.06

\author{
V.P. PANTELEIEV, \\ Dsc (Economics), Professor of Accounting \\ and Taxation Department, \\ National Academy of Statistics, Accounting and Audit; \\ ResearcherID: $J-1868-2018$; \\ M. V. NASTENKO, \\ PhD (Economics), Lecturer of Accounting \\ and Taxation Department, \\ Vinnytsia Institute of Trade and Economics \\ of Kyiv National University of Trade and Economics
}

\title{
Tax Culture of Employees of the Enterprise
}

By the standard of relation of workers of enterprise to implementation of duties in relation to tax payment in a budget there must be an imperative of the USA and most capitalist countries: taxes are paid undoubtedly in the rules and terms marked Law. In these countries cultural traditions and honor are formed and supported to supremacy of interests of society and state. 'Tax culture of workers' as interdisciplinary study, proposing his phenomenon that was not able to have a presentiment in any other way. With hope, we will testify the theory of tax culture, that confidently moves after clean hypothetical political, economic, and social study, in the near future. Besides, reasoning recommendations can be got from the concept of tax culture of workers, that in the end will result in higher and more viable tax profits to more legal tax state as well as more transparent tax mode.

The article reveals measures to introduce tax culture, which contribute to the motivational mechanism of economic regulation. The role of the tax culture in the field of taxation is described, the rules for the implementation of tax culture at the enterprise of Ukraine in the administration of taxes and fees are set forth, the author's definition of tax culture is formulated, the experience of EU countries in using cultural traditions in accounting for tax liabilities and the application of effective management tools is shown; the sequence of promotion of the problems of tax administration with application of tax culture is given.

Keywords: taxes, internal tax culture, administration of taxes and fees, accounting.

Problem setting. Implementation of requirements of tax law becomes an imperative, by the dominant of professional activity in an enterprise; the requirements of addition to the budgets are laid receivables in basis of administration of taxes and collections. Largely a record-keeping and financial reporting is inferior to the requirements of taxation. At the same time the subjects of manage have a right on the use of alternative norms of tax law. A question appears how to use the mechanism of tax culture (cultures of taxation) for administration of taxes and collections on the enterprises of Ukraine. Research is from the corresponding range of problems from the accounting-fiscal point of view

Literature review. The motivational planes of system, complex and local mechanisms of the tax adjusting are offered [1]; scientists are attribute the professionally-ethic norms of accountants to the informal institutes of book-keeping theory [2], behaviours reasons of workers are included in internal institutional factors [3]; researchers are offer a few appropriate determinations of tax culture $[4 ; 5]$; creation of tax ideology and increase of tax culture [6] it is considered the important factor of observance of requirements of taxation and providing of effectiveness of management an enterprise. But maintenance of internal culture of enterprise in relation to providing of implementation of requirements of taxation is exposed still not enough.

The aim of this research is illumination of scientific and practical principles of successful implementation of mission of enterprise through the use of factor of internal tax culture of enterprise.

(C) V. P. Panteleiev, M. V. Nastenko, 2018 


\section{Exposition of basic material. \\ The role of tax culture is in the sphere of taxation}

In the humanistic measuring a culture represents quality lines and features of management an enterprise, more precisely - she represents totality of knowledge, abilities and actions, their structure and depth, world view, mental and ethical norms of work, relation of workers of enterprise to labour, skills of workers in organization of work, aspiration of employees to see the cultural values of enterprise and hear the confession them, ability of workers to control a temper and understand the features of working as the row of people.

Guidance of society, in thereby him the tax system uses traditions, spiritual, cultural values and system of record-keeping, that was folded in the state. There is a certain hierarchy of constituents of culture in society: more wide circle is a national culture, culture of society, cultural environment, unique cultural values, traditions and customs of every people; a rich in content narrow circle is a corporate culture, legal culture, economic culture (business-culture); in the same circle there is a tax culture (a synonym is a culture of taxation) that is base on norms of tax law, foremost on the norms of the Tax code of Ukraine [7], the requirements of this circle of culture are obligatory for the public servants of fiscal and custom services, experts, civil servants, teachers of educational establishments and others like that; in a middle circles are taxpayers (legal and natural persons), that generate the internal organizational culture, corporate culture and behaviour of workers(an acceptance/of avoidance of risk, organization of breach, is in business due to innovations, ideological aspirations of workers are exposed mission of corporation and others like that), culture of management an enterprise, culture of record-keeping, culture of operations from taxation on an enterprise control culture, culture of audit, finally culture of implementation of tax duties by a employees.

The theorists of economic science did the payment in combination of sociology, management and taxation. The "classic" understanding of "tax culture", set forth by the Austrian and American economist, sociologist and historian of economic ideas Joseph Alois Schumpeter (1883-1950) in 1929, there are "Economy and sociology of income-tax" in the article, marking that a tax culture is expression of human spirituality and work. But it was almost fully limited to the creators of the tax system. In other words, 90 ago taxpayers ignored part of "tax culture". Term "tax culture" next interpretations; however, concentrates attention first of all on a communalisation between taxpayers and tax organs. Appropriately to mark absence in the Tax code of Ukraine of positions about a culture, but he contains directive positions about rights and duties of taxpayers, right and duties of public servants of supervisory organs, administration of taxes, collections (obligatory payments) division of II Tax code of Ukraine, public servants of organs of government tax service and them legal defence Division XVIII and division of XVIII the Tax militia and others like that [7].

Scientists are offer reasonable determination of actual tax culture, now such definitions it is known already more than 10. For example, a national tax culture is necessary to be all-round defined as integrity of all relevant formal and informal establishments of the national tax system, that is historically formed within the limits of supersystems culture of country, including the relations caused them by the protracted co-operation [5]. On opinion of $\mathrm{H}$. Yu. Kucherova, tax cultures presents by a system of knowledge, values, presentations, that exist in consciousness of citizens and formed on tax traditions totality of that stipulates the form of intersectional co-operation of taxpayers with state institutes concerning taxation [4].

Definitions of tax culture are above-mentioned correct and have having a special purpose character. At the same time, it is taken not enough into account researchers that a tax culture develops in the river-bed of activity of taxpayer, id est at administration of taxes and collections of enterprise. Under administration of taxes and collections in enterprises totality of actions of public servants of enterprises-taxpayers understands in relation to organization of account, control, management after an extra charge and tax, collections, payments payment in accordance with the order set by a law. To the basic measures from administration of taxes and collections on enterprises belong: conduct in accordance with established procedure of accounting of incomes and charges, stowage of accounting that touches a calculation and tax payment and collections, including the financial reporting; electing independently of method of registering of profits and charges; using tax deductions is at presence of grounds; receipt of postponement, arranging on the instalment system of tax or tax credit payment all right and on the terms set by Tax Code; presentation is to the supervisory organs in the order set by a tax and custom law, declarations, accounting and other documents related to the calculation 
and tax and collections payment; tax and collections payment in terms and in the sizes set by Tax Code of Ukraine and laws on questions custom business; use of mechanism of motivation of workers in relation to the observance of norms of internal tax culture, presentation of the legal interests in supervisory organs in behalf on a taxpayer and others like that. Close connection of tax culture with aspects other researchers confirm administration of taxes and tax discipline [4].

Going out such understanding straight to activity of enterprise, it is possible to offer next determination of tax culture is the part of national culture of country, related to activity of participants of the relations, managed by a legislation about taxes and collections and state, that represents the level of knowledge and observance of tax law, rightness of calculation, plenitude and timeliness of inpayment (enumeration) in the budget of Ukraine of taxes, collections and other obligatory payments, knowledge of the rights, implementation of the duties, that consists of understanding all employees of importance of tax payment for society, states and enterprise.

\section{Practices of input of tax culture}

On Table 1 with the use of approach of the systems the rules of realization of tax culture are expounded on an enterprise during realization of administration of taxes and collections of enterprise.

Table 1

Substantive provisions of realization of tax culture are on an enterprise

\begin{tabular}{|c|c|}
\hline $\begin{array}{l}\text { Elements } \\
\text { of tax culture }\end{array}$ & $\begin{array}{c}\text { Opening of maintenance of elements of tax culture is } \\
\text { during realization of administration of taxes } \\
\text { and collections of enterprise }\end{array}$ \\
\hline 1 & 2 \\
\hline $\begin{array}{l}\text { Substantive provisions } \\
\text { and methods of adminis- } \\
\text { tration of taxes }\end{array}$ & $\begin{array}{l}\text { Analysis of the tax loading, taking into account of tax risks, } \\
\text { preparation and acceptance of administrative decisions in the } \\
\text { field of taxation, tax management, realization of select tax } \\
\text { politics, account of calculations after taxes, formation of centres } \\
\text { of responsibility, tax budgeting (budgets of separate taxes and } \\
\text { general tax budget of enterprise), tax pay calendar, internal } \\
\text { budgetary (tax) control, internal tax accounting }\end{array}$ \\
\hline $\begin{array}{l}\text { An account of } \\
\text { calculations is after taxes }\end{array}$ & $\begin{array}{l}\text { Account of tax base, tax obligations, tax debt, observance of terms } \\
\text { of tax payment liquidation }\end{array}$ \\
\hline $\begin{array}{l}\text { Objects of tax } \\
\text { administration }\end{array}$ & $\begin{array}{l}\text { Financial relations by taxpayers and public supervisory organs in } \\
\text { relation to an extra charge and tax, collections payment }\end{array}$ \\
\hline $\begin{array}{l}\text { Forming and observance } \\
\text { of tax politics (politicians } \\
\text { of account of calculations } \\
\text { are after taxes) }\end{array}$ & $\begin{array}{l}\text { Choice of form of record-keeping and account of calculations } \\
\text { after taxes, establishment of working card of accounts, accounts } \\
\text { of account of charges, accounts of account of taxes, confession } \\
\text { of standards of account, after that a record-keeping is conducted } \\
\text { and there is the financial reporting, electing of methods of account } \\
\text { after objects: the fixed assets, supplies, non-material assets, } \\
\text { income tax, tax value-added (VAT) and other [8] }\end{array}$ \\
\hline $\begin{array}{l}\text { Reflection of taxes } \\
\text { and collections on the } \\
\text { accounts of record- } \\
\text { keeping }\end{array}$ & $\begin{array}{l}\text { Prime price of realization of products, administrative charges, } \\
\text { other charges, profits of physical persons, indirect taxes and } \\
\text { others like that }\end{array}$ \\
\hline $\begin{array}{l}\text { Implementation of } \\
\text { operations workers } \\
\text { is from a record- } \\
\text { keeping and account of } \\
\text { calculations after taxes }\end{array}$ & $\begin{array}{l}\text { Collation of information with the integrated card of payer of tax, } \\
\text { work with remarks in the acts of verification from the organs of } \\
\text { State Fiscal Service of Ukraine (SFS), preparation of denial to the } \\
\text { act of confession, extra charge of tax, reduction of excessive extra } \\
\text { charge of sum of tax, correction of errors at the extra charge of } \\
\text { tax, extra charge and reflection at a record-keeping and inpayment } \\
\text { of fine and fine; adjustment of forms of the financial reporting, } \\
\text { repeated promulgation of the financial reporting, stowage of } \\
\text { specifying declarations (calculations), challenging of sums of }\end{array}$ \\
\hline
\end{tabular}




\begin{tabular}{|l|l|}
\hline \multicolumn{1}{|c|}{$\mathbf{1}$} & \multicolumn{1}{|c|}{$\mathbf{2}$} \\
\hline & $\begin{array}{l}\text { taxes, appeal of decisions of organs of SFS, in the administrative } \\
\text { or judicial order, inpayment of administrative fines, stowage of } \\
\text { reports on the sums of tax deductions, use of the Electronic cabinet } \\
\text { of payer, using the system of electronic administration of VAT, } \\
\text { timely filling of registers of the tax superimposed/calculations of } \\
\text { adjustment, reflection in the account of results of verifications, } \\
\text { counts of tax, avoidance of unreliable information and confessions } \\
\text { of operations invalid }\end{array}$ \\
\hline $\begin{array}{l}\text { Subjects of tax adminis- } \\
\text { tration of enterprise }\end{array}$ & $\begin{array}{l}\text { Subdivisions of enterprise, workers, office workers that is } \\
\text { provided with plenary powers to conduct tax administration on } \\
\text { an enterprise }\end{array}$ \\
\hline $\begin{array}{l}\text { Occupational take of ac- } \\
\text { countant }\end{array}$ & $\begin{array}{l}\text { Actions or inactivity of workers of book-keeping service, that } \\
\text { instigate to the possible danger of curvature of book-keeping } \\
\text { information, caused by thriftless ness, wastefulness or book that } \\
\text { results in sustain losses an enterprise cooking }\end{array}$ \\
\hline $\begin{array}{l}\text { Subjects of tax culture of } \\
\text { enterprise }\end{array}$ & $\begin{array}{l}\text { It is workers of subdivisions of enterprise : security services, } \\
\text { legal service, information technologies, sales department, book- } \\
\text { keeping, managers, in particular, tax managers, internal public } \\
\text { accountants and others like that }\end{array}$ \\
\hline
\end{tabular}

Source: made by the author

Appropriately to add important aspects in relation to the rich in content filling of category tax culture. It, for example, forming of open and closed state information culture, opening of information about a culture in Report on a management, additional informing for the subjects of public interest, use of methods of estimation, criteria, input of control, internal audit, economic analysis, sociological researches. Separate attention is needed by establishment of influence of culture of activity of accountants and book-keeping of enterprise on efficiency of activity of enterprise through realization of account and taxation, decline of occupational take of accountant and others like that.

\section{A tax culture of enterprise is in adjusting of economy}

Essence of internal tax culture of enterprise can be expounded in a next form (Table 2). Table 2

Table of contents of internal tax culture of enterprise

\begin{tabular}{|l|l|}
\hline \multicolumn{1}{|c|}{$\begin{array}{c}\text { Constituents } \\
\text { of tax culture }\end{array}$} & \multicolumn{1}{c|}{ Opening of constituents of culture } \\
\hline \multicolumn{1}{|c|}{$\mathbf{1}$} & \multicolumn{1}{c|}{$\mathbf{c}$} \\
\hline Aim & $\begin{array}{l}\text { Formation and support of the system of values, norms and ideals that is } \\
\text { divided and used by the workers of enterprise and sent to implementation } \\
\text { of duties in relation to taxes }\end{array}$ \\
\hline Policy & $\begin{array}{l}\text { Declaration of select style of internal culture: market culture, clan cul- } \\
\text { ture, culture of enterprise, culture of mission and others like that. Choice } \\
\text { and introduction of measures in relation to the motive of all workers to } \\
\text { desirable behaviour for the sake of observance of the confessed positions } \\
\text { from taxes, forming of desirable model of tax behaviour of personality } \\
\text { and irreconcilable relation of personnel to ignoring the requirements } \\
\text { of taxation }\end{array}$ \\
\hline $\begin{array}{l}\text { Internal } \\
\text { normatively-legal } \\
\text { acts }\end{array}$ & $\begin{array}{l}\text { Pointing of person that is responsible for the system of internal tax } \\
\text { culture of enterprise, development of Statute about the internal culture } \\
\text { of enterprise, Code of professional ethics of workers of enterprise in } \\
\text { that the models of tax behaviour of personality register and other }\end{array}$ \\
\hline
\end{tabular}


Table 2

\begin{tabular}{|l|l|}
\hline \multicolumn{1}{|c|}{$\mathbf{1}$} & \multicolumn{1}{|c|}{$\mathbf{2}$} \\
\hline Providing & $\begin{array}{l}\text { Estimation of the executed work, estimation of risks (threats to violation } \\
\text { of requirements of tax culture); development of criteria of observance of } \\
\text { culture, analysis of fluidity of shots, loss of skilled shots and bringing in } \\
\text { of specialists, that divide the ideals of enterprise, motivational system } \\
\text { and others like that }\end{array}$ \\
\hline Introduction & $\begin{array}{l}\text { Stimulation of increase of internal tax culture of enterprise, support of } \\
\text { continuous studies and general use of knowledge, adaptation of culture } \\
\text { to activity of enterprise, cultural selection, providing of durability of } \\
\text { culture, overcoming of resistance of input of politics of culture and } \\
\text { others like that }\end{array}$ \\
\hline $\begin{array}{l}\text { Realization of poli- } \\
\text { tics of culture }\end{array}$ & $\begin{array}{l}\text { Strengthening of powers of collection and control, documenting of } \\
\text { procedures of taxation, analysis of interview, questionnaire/of testing } \\
\text { of employees, inspection of behaviour, reacting on signals, acceptance } \\
\text { of measures of caution, decision of critical situations and conflict of } \\
\text { interests, maintenance of balance between the atmosphere of trust and } \\
\text { demand on an enterprise and others like that }\end{array}$ \\
\hline
\end{tabular}

Source: made by the author

Appropriately to distinguish the corresponding types of tax culture :

- at the level of knowledge of person about tax processes and features of making decision in the environment of taxation;

- at the level of feelings of people to the elements of the tax system, implementation of corresponding tax roles specialists;

- $\quad$ at the level of evaluation, judgements, ideas and presentations of people about tax processes and tax system;

- $\quad$ at the level of models of tax behaviour of personality and others like that [4].

\section{Vital school of countries of $\mathbf{E U}$}

During realization of euro vector of development of Ukraine it follows to bear in a mind the prospects of removal of custom barriers between the countries of EU, about the general system of tax value-added and also strengthening and strengthening of the collaboration sent to perfection and development of the tax system EU and tax organs of Ukraine [9]. These administrative decisions that all countries-members of EU adhere to unavoidable will find a reflection in administration of taxes and culture of taxation in Ukraine.

Long-term experience of integration, harmonization of processes of account and taxation in the countries of EU is base on the formed high tax culture as taxpayers so office workers of fiscal organs. Considerable influence on organization of record-keeping and account of calculations cultural traditions of separate countries have after taxes. It is necessary to take into account differences in socio-economic traditions of participating countries of EU.

For example, in France influence of culture finds a reflection in bureaucracy and propensity to power, there is dependence of the fiscal accounting on book-keeping [10]. Therefore the single compatible system of account, that is orientated on the informative providing of public planning organs, is used in France. In reports distribution of taxes of company is represented on results from the unbiased types of activity and, the results of influence open up other results that specify on the applied book-keeping method of account on incomes, losses and equity from tax requirements [11, p. 197]; in the complement of obligatory forms of annual reports Report enters also on gains and losses, the form of that is plugged in Decree about tax. In France the dedicated (simplified) tax modes are used for small and middle enterprises depending on the size of their turn. Such enterprises do not give declaration about VAT, however pay income-taxes the level of that depends on the sphere of activity (trade operations, services and others like that) [12]. 
Influence of culture of Germany shows up in a grant to priority to the norms of right. An account in Germany considerably is more conservative and intended foremost for defence of interests of banks [10]. The basic difference of the German system of taxation is possibility for the payer of income tax to choose one of two variants of collection of information about an income (loss) in the system of current account - after principles or book-keeping (trade) balance or tax balance. The tax rates of depreciation are near to the real norms and looked over regularly. Therefore most enterprises at the stowage of the financial reporting use the tax rates of depreciation for simplification of stowage of the financial and tax reporting [13]. The network of professional tax consultants functions in a country.

Influence of culture of Great Britain finds a reflection in priority of traditions. An account in Great Britain is oriented to providing of investors of и creditors by information necessary to them for the acceptance of administrative decisions [10, p. 47]. In Great Britain a taxpayer can choose such variant of taxation, that will be for him effective. Such moment diminishes the shadow sector of economy and abbreviates the amount of defaulters. One of the most widespread forms of stimulation of development of sector of small enterprise in the developed countries of Europe there is creation for them of advantage (privilege) in taxation by application of general rules with separate privileges for small enterprises. The simplified system of account and accounting of Great Britain consists in that enterprises with annual earnings to 15 thousand pound sterlings fill out simple tax declaration without the detailed data about the activity or assets or obligations.

\section{Problems of adaptation of tax culture}

For successful motivation to tax, reduction of scales of avoiding payment implementation of duties of taxpayer and others like that only not enough to development of tax culture on enterprises. Forming of trust to the institutes of power, decline of level of shadow economy and corruption in a country and other will substantially assist filling of budget and realization of important principle of tax law of Ukraine - fiscal sufficiency [7]. To the basic problems it costs to reckon first of all, and it is one of principal reasons, low level of tax culture and tax discipline of taxpayers, that results in violation of tax law [14]. The elements of tax culture also are tax education and literacy. Tax discipline and in the field of taxation comes forward an awareness as one-sided and examined only from position of taxpayers. In these determinations many-sided nature and complication of concept "tax culture" are illuminated only partly [4]. The legal aspect of tax culture contains indissoluble connection of compulsion and convinced of right envisages law consequences for the threat of application of force measures on forming of persuasion of subject in a necessity legitimate behaviour. It follows to extend the institutional circle of subjects of tax relations of Ukraine with an inherent by him tax culture, plugging tax and legal consultants in him, book-keeping and public accountant firms and others like that, that give to the taxpayers service from doing business.

\section{Summary}

Research of experience of development of economy of Ukraine specified the appropriateness of application of scientific tool to the study of tax culture of workers of enterprises as important constituent of motivational mechanism of adjusting of economy. Taking into account of tax culture at administration of taxes and collections of enterprisetaxpayer the new aspects of culture allowed to expose. The study of cultural descriptions of registering and taxation of subjects of ménage witnessed the appropriateness of co-operation of taxpayers as an important component of culture of society.

Further interdisciplinary researches that embrace the economic, social, legal, ethic aspects of public relations of extra charge and tax payment are needed. Appropriately in composition registration politics of enterprise to distinguish politics of account of calculations after taxes. Without regard to different priorities in an economy, differences in cultural traditions of separate countries that is included in EU, in these countries tax obligations are successfully represented in an account and the effective instruments of management are used : dedicated modes of taxation, simplified rules of account and taxation of small business, privilege entities in taxation and others like that. The value of tax culture of enterprise envisages steady advancement of range of problems of administration of taxes in 
a next sequence: establishment of model of co-operation of record-keeping and account of calculations after the taxes $\rightarrow$ of inhibition of select tax ideology (tax culture and moral, professional ethic norms) $\rightarrow$ workers the absolute following by workers to the norms of tax law $\rightarrow$ of maintenance of high image of enterprise as a conscientious(irreproachable) taxpayer, avoidance of fines, fine; receipt of tax incentives.

\section{References}

1. Ivanov Yu. B., Yeskov O. P. (2007). Suchasne opodatkuvannia: motyvatsiinyi aspekt [The modern taxation: motivational aspect]. Kharkiv: VD INZhEK [in Ukrainian].

2. Bezverkhyi K. (2014). Instytutsionalna model bukhhalterskoho obliku v Ukraini [The institutional model of accounting in Ukraine]. Bukhhalterskyi oblik $i$ audyt-Accounting and auditing, 10, 32-41 [in Ukrainian].

3. Pankov V. V. (2011). Institutsionalnaya teoriya buhgalterskogo ucheta $i$ audita [The institutional theory of accounting and audit]. Moskva: InformByuro [in Russian].

4. Kucherova H. Yu. (2015). Podatkova kultura yak eterminant suchasnoho opodatkuvannia v Ukraini [The tax culture as a determinant of the modern taxation in Ukraine]. Teoretychni i praktychni aspekty ekonomiky ta intelektualnoi vlasnosti-Theoretical and practical aspects of economics and intellectual property, vol. 2, issue 2(12), 51-55 [in Ukrainian].

5. Melnyk O. Y. (2015). Core concepts of tax culture. Zovnishnia torhivlia: ekonomika, finansy, pravo - Foreign trade: economics, finance, law, 5-6 (82-83), 125-128.

6. Tymoshenko O. V. (2014). Vplyv systemy opodatkuvannia pidpryiemstva na ekonomichnu bezpeku derzhavy [The taxation system's effects for the economic security of the state]. Biznes-Inform - Business Inform, 9, 234-240 [in Ukrainian].

7. Podatkovyi kodeks Ukrainy vid 02.12.2010 r. No 2756-VI [The Tax Code of Ukraine from 02.12.2010 No 2756-VI]. Retrieved from http://search. Ligazakon.ua [in Ukrainian].

8. Metodychni rekomendatsii z oblikovoi polityky pidpryiemstva: Nakaz MFU vid 27.06.2013 No 635 [Methodical recommendations for the accounting policy of the enterprise. The Order of the Ministry of Finance of Ukraine from 27.06.2013 No 635]. Retrieved from http: // search. Ligazakon.ua [in Ukrainian].

9. Uhoda pro asotsiatsiiu mizh Ukrainoiu, z odniiei storony, ta Yevropeiskym Soiuzom, Yevropeiskym spivtovarystvom $\mathrm{z}$ atomnoi enerhii i yikhnimy derzhavamy-chlenamy, $\mathrm{z}$ inshoi storony. Uhodu ratyfikovano iz zaiavoiu Zakonom No 1678-VII vid 16.09.2014 [Association Agreement between Ukraine, on the one part, and European Union, European Atomic Energy Community and their member states, on the other part. The Agreement was ratified with a statement by Law No 1678-VII dated September 16, 2014]. Retrieved from zakon.rada.gov.ua/laws/show/984_011. [in Ukrainian].

10. Müller G., Gernon H. B. Miike G. (1992). Uchet: Mezhdūnarodnaya perspektiva [Accounting: the international perspective]. Translated from English. Moskow: Finance and Statistics [in Russian].

11. Blake J., Amat O. (1997). Evropeyskiy buhgaterskiy uchet. Spravochnik [The European accounting. Directory]. Translated from English. Moscow: Information and publishing house "Filin" [in Russian].

12. Sopko V., Andros S. Finansovi zvity u systemi upravlinnia: dosvid Frantsii [Financial reports in the management system: French experience]. Retrieved from 2010http:/ena. lp.edu.ua/bitstream/ntb/11941/1/128.pdf [inUkrainian].

13. Malyshkin O. (2014). Osoblyvosti opodatkuvannia prybutku korporatsii i yoho oblik na pidpryiemstvakh Nimechchyny [Specific features of corporate profit taxation and accounting at German enterprises]. Bukhhalterskyi oblik $i$ audit-Accounting and auditing, 2, 44-52 [in Ukrainian].

14. Dehtiarova S. (2017). Rol podatkovoho navantazhennia yak osoblyvoho skladnyka [The role of tax burden as a special component]. Administratyvne pravo i protses Administrative law and process, 5, 104-107 [in Ukrainian]. 
В. П. ПАНТЕЛЕСВ,

доктор економічних наук, професор кафедри обліку та оподаткування,

Національна академія статистики, обліку та аудиту;

М. Н. НАСТЕНКО,

кандидат економічних наук,

доцент кафедри обліку та оподаткування,

Вінницький торговельно-економічний інститут Київького національного торговельно-економічний університету

\section{Податкова культура працівників підприємства}

У статті розкрито заходи із впровадження податкової культури, які сприяють мотиваційному механізму регулювання економіки. Вказано роль податкової культури в сфері оподаткування, викладено правила реалізачії податкової культури на підприємстві при проведенні адміністрування податків та зборів, сформульовано авторське визначення податкової культури, показано досвід краӥн ЄС у використанні культурних традицій в обліку податкових зобов'язань та застосуванні ефективних інструментів управління; наведено послідовність просування проблематики адміністрування податків із застосуванням податкової культури.

Ключові слова: податки, внутрішня податкова культура, адміністрування податків та зборів, бухгалтерський облік.

В. П. ПАНТЕЛЕЕВ,

доктор экономических наук, профессор кафедры учета и налогообложения, Национальная академия статистики, учета и аудита;

М. Н. НАСТЕНКО, кандидат экономических наук, доиент кафедры учета и налогообложения,

Винницкий торгово-экономический институт Киевского начионального торгово-экономического университета

\section{Налоговая культура работников предприятия}

В статье раскрыты меры по внедрению налоговой культуры, которые способствуют мотивационному механизму регулирования экономики. Указана роль налоговой культуры в сфере налогообложения, изложены правила реализации налоговой культуры на предприятии при проведении администрирования налогов и сборов, сформулировано авторское определение налоговой культуры, показан опыт стран ЕС в использовании культурных традиций в учете налоговых обязательств и применении эффективных инструментов управления; приведена последовательность продвижения проблематики администрирования налогов с применением налоговой культурье.

Ключевые слова: налоги, внутренняя налоговая культура, администрирование налогов и сборов, бухгалтерский учет.

Bibliographic description for quoting:

Panteleiev V. P., Nastenko M. V. (2018). Tax Culture of Employees of the Enterprise. Scientific Bulletin of National Academy of Statistics, Accounting and Audit - Naukovyy visnyk Natsionalnoyi akademiyi statystyky, obliku ta audytu, 4, 58-65 [in English]. 